\title{
Estimating mass-wasting processes in active earth slides - earth flows with time-series of High-Resolution DEMs from photogrammetry and airborne LiDAR
}

\author{
A. Corsini ${ }^{1}$, L. Borgatti ${ }^{2}$, F. Cervi ${ }^{1}$, A. Dahne ${ }^{1}$, F. Ronchetti $^{1}$, and P. Sterzai ${ }^{3}$ \\ ${ }^{1}$ Department of Earth Sciences, Modena and Reggio Emilia University, Modena, Italy \\ ${ }^{2}$ Department of Structural, Transport, Hydraulic, Survey and Territorial Engineering - DISTART, Bologna University, \\ Bologna, Italy \\ ${ }^{3}$ National Institute of Oceanography and Experimental Geophysics - OGS, Trieste, Italy
}

Received: 1 December 2008 - Revised: 6 March 2009 - Accepted: 9 March 2009 - Published: 19 March 2009

\begin{abstract}
This paper deals with the use of time-series of High-Resolution Digital Elevation Models (HR DEMs) obtained from photogrammetry and airborne LiDAR coupled with aerial photos, to analyse the magnitude of recently reactivated large scale earth slides - earth flows located in the northern Apennines of Italy. The landslides underwent complete reactivation between 2001 and 2006, causing civil protection emergencies. With the final aim to support hazard assessment and the planning of mitigation measures, highresolution DEMs are used to identify, quantify and visualize depletion and accumulation in the slope resulting from the reactivation of the mass movements. This information allows to quantify mass wasting, i.e. the amount of landslide material that is wasted during reactivation events due to stream erosion along the slope and at its bottom, resulting in sediment discharge into the local fluvial system, and to assess the total volumetric magnitude of the events. By quantifying and visualising elevation changes at the slope scale, results are also a valuable support for the comprehension of geomorphological processes acting behind the evolution of the analysed landslides.
\end{abstract}

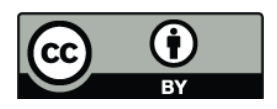

Correspondence to: A. Corsini (alessandro.corsini@unimore.it)

\section{Introduction}

High-Resolution Digital Elevation Models (HR DEMs) have proved to be useful in the analysis of landslide processes from different perspectives and at different spatial scales, including improvement of landslide inventories, susceptibility assessment and appraisal of landslide surface features (Van Westen and Lulie Getahun, 2003; McKean and Roering, 2004; Casson et al., 2005; Metternicht et al., 2005; Glenn et al., 2006; Jaboyedoff et al., 2007).

In this work, the analysis of recent reactivation events of large scale earth slides - earth flows in the northern Apennines of Italy was carried out by means of HR DEMs, obtained with photogrammetry and airborne LiDAR.

The final objective was to gain new pieces of knowledge to be used for hazard assessment and planning of mitigation measures in these case studies. Specific aims were: interpreting and quantifying processes of depletion and accumulation at the slope scale, quantifying mass wasting at the slope scale (i.e. the amount of landslide material that is wasted during reactivation events due to stream erosion along the slope and at its bottom and that results in sediment discharge into the local fluvial system) and assessing the total volumetric magnitude of the events.

\section{Test sites}

The Valoria and the $\mathrm{Ca}$ ' Lita landslides are located in the northern Apennines (Fig.1). They are large scale rototraslational earth slides - earth flows affecting weak rock masses, i.e. flysch and clayey mélanges. Both landslides have

Published by Copernicus Publications on behalf of the European Geosciences Union. 


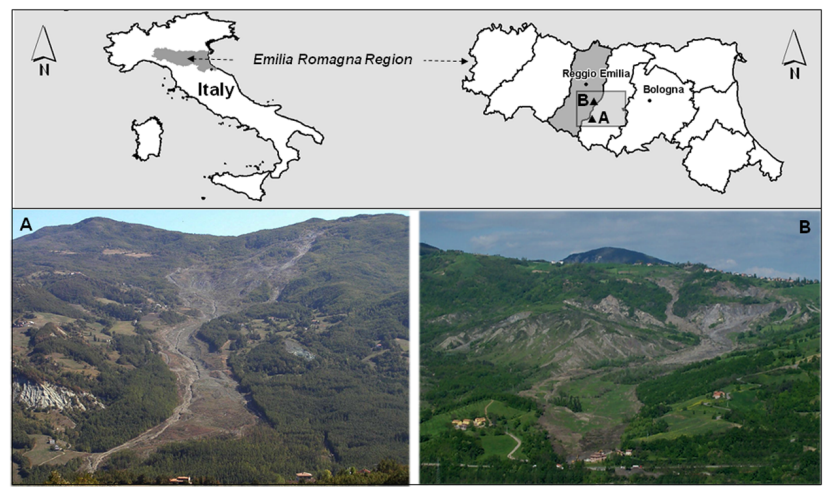

Fig. 1. Panoramic view of the test sites. (A) Valoria landslide; (B) Ca' Lita landslide.

a length of about $3 \mathrm{~km}$, involve areas of about $1 \mathrm{~km}^{2}$, and move at depths ranging from $10 \mathrm{~m}$ to $30-40 \mathrm{~m}$. Total landslide volume of each phenomenon exceeds 25 million $\mathrm{m}^{3}$ (Borgatti et al., 2007; Ronchetti et al., 2007).

The Valoria landslide was reactivated in 2001 (Fig. 1a). The 2001 reactivation affected about $70 \%$ of the slope recognised, on the basis of geomorphologic interpretation, as being part of a pre-historic landslide, radiocarbon dated to 7800-7580 cal. yr BP (Bertolini, 2007). Historic records collected by Regione Emilia-Romagna (2008) indicate that events of a much smaller magnitude of that of 2001, occurred in the years 1950 and 1984 . In these cases, only a limited portion of the landslide was remobilised (Manzi et al., 2004). During 2001 reactivation, part of the earth flow invaded the riverbed and the ancient landslide toe was remobilised in bulk.

A second total reactivation event occurred in winter 20052006. In this case, the earth flow lobe didn't reach the valley floor (Ronchetti et al., 2007). During this reactivation, maximum velocities were in the order of $10-20 \mathrm{~m} /$ day. Today the landslide is still active, with movements affecting the source area, the transit zone, the toe.

The Ca' Lita landslide (Fig. 1b) was reactivated in 2002 and again in 2004 (Borgatti et al., 2006). The 2002 and 2004 reactivations affected about $60 \%$ of the slope recognised, on the basis of geomorphologic interpretation, as being part of a pre-historic landslide complex. Unlike Valoria, no radiocarbon date is available to frame in time the origin of the mass movement. However, several reactivations of a much smaller magnitude of that of 2002 and 2004 have occurred in period 1950 to 1985 (Regione Emilia-Romagna, 2008). During the 2004 reactivation, the landslide toe advanced for about $400 \mathrm{~m}$ into a previously unaffected valley floor, and buried it completely (Borgatti et al., 2006). During reactivation, maximum velocities were in the order of $10 \mathrm{~m} /$ day. Today the landslide is inactive (suspended to dormant), thanks also to the heavy countermeasure works carried out in the slope (Corsini et al., 2006; Borgatti et al., 2008).

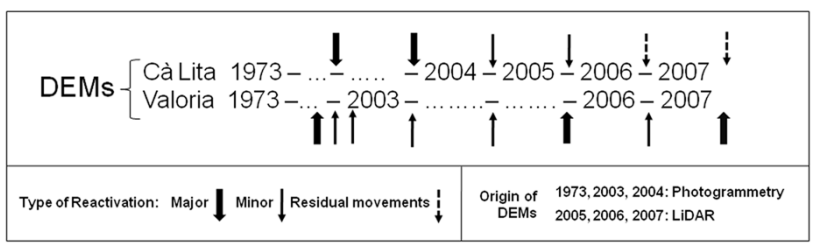

Fig. 2. Time series of DEMs put in relation to subsequent reactivation events of the Valoria and Ca' Lita landslides.

\section{DEMs time series}

The time series of DEMs available for Valoria and Ca' Lita landslides are summarised in Fig. 2.

The 1973 DEMs for both sites were generated by digitisation of official 1:5000 topographic maps (created by supervised photogrammetry). The 2003 and 2004 DEMs were also created by supervised photogrammetry at 1:2000 reference scale. They're based on ad hoc aero-photographic surveys carried out by public authorities soon after the reactivation events. In all these cases, DEMs were calculated using a $2 \mathrm{~m}$ grid cell size by interpolating contours with the Borgefors distance transform function available in software ILWIS (Gorte and Koolhoven, 1990).

The 2005, 2006 and 2007 HR-DEMs were obtained with airborne LiDAR. Surveys were performed with a helicoptermounted Optech ALTM 3100 laser scanner system that is able to record up to 4 returns. Range measurement frequency was set to $50 \mathrm{kHz}$ to balance between density of survey points and noise. The laser beam divergence of $0.2 \mathrm{mrad}$ results in a footprint of $0.17 \mathrm{~m}$. At an average flight altitude of $800 \mathrm{~m}$, the acquisition parameters allowed to obtain an average data density of about 3 to 4 points $/ \mathrm{m}^{2}$. Processing of on-board GPS and IMU data yielded a position accuracy of ca. $0.5 \mathrm{~m}$ in easting ad northing and an absolute accuracy of $0.15 \mathrm{~m}$ in elevation. Every single geocoded laser point was classified using Terrascan software (Terrasolid, 2005) in order to retrieve only those points that were associated with a "bare ground" reflector. DEMs of ground elevation were generated by as grids of $0.5 \mathrm{~m}$ cell size (Corsini et al., 2007) using the triangulation with linear interpolation method, with anisotropy parameters ratio $=1$ and angle $=0$. Such method is based on the algorithm presented in Guibas and Stolfi (1985).

It must be anticipated that the systematic analysis of the bias between the DEMs and the confidence interval in stable areas and in vegetated areas was out of the scope of this work. On a semi-quantitative basis, it can be stated that the bias in non vegetated stable areas between photogrammetric DEMs was in the range of $+/-1 \mathrm{~m}$, increasing to $+/-2 \mathrm{~m}$ in vegetated stable areas. Between LiDAR DEMs the bias was generally in the range of $+/-0.25 \mathrm{~m}$ in stable non vegetated areas and of about $+/-0.5 \div 1 \mathrm{~m}$ in stable vegetated areas. However, it is important to stress that since the morphological changes induced by the reactivation events were 


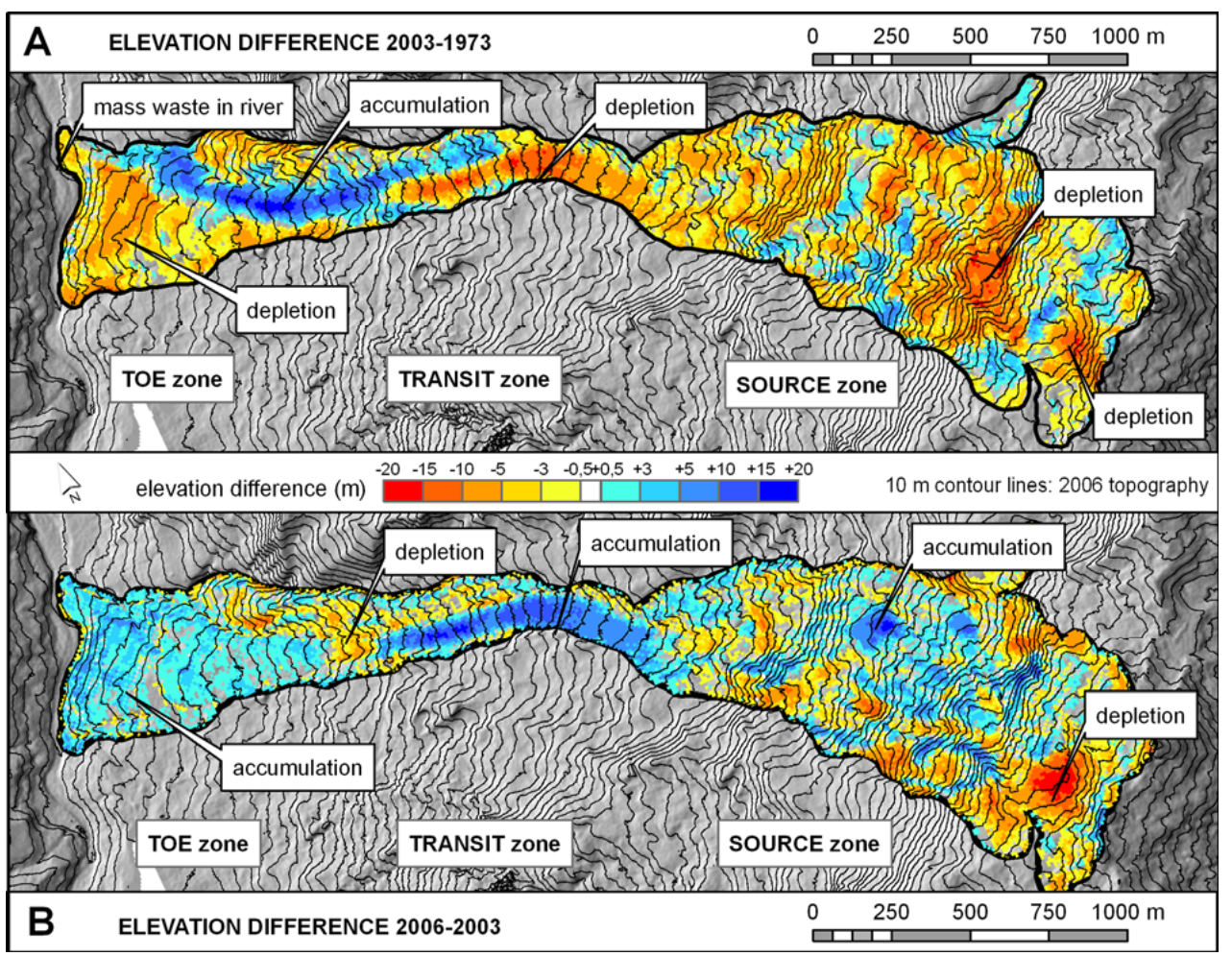

Fig. 3. Differential DEMs for the Valoria landslide. (A) differential DEM 2003-1973; (B) differential DEM $2006-2003$.

in the order of meters, biases between DEMs had a limited negative effect on the interpretation of landslide processes. Moreover, by calculating depleted and accumulated volumes in a supervised manner, and only in mostly non vegetated landslide areas, the negative effect of bias is to be considered reasonably low also on the quantitative assessment of mass transfer along the slope.

\section{Differential DEMs}

\subsection{Valoria landslide}

A first differential DEM product was created by subtraction of the 1973 and 2003 DEMs. This time interval brackets the 2001 reactivation event (Fig. 3a). It must be specified that the subdivision of the landslide in source, track and toe zones, as indicated in Fig. 3, is based on geomorphologic observation and mapping during field surveys and photo interpretation and, therefore, does not result from any algorithm related to DEMs. The differential DEM product evidenced significant distributed depletion in the source zone and in the transit zone of the landslide (down to $-20 \mathrm{~m}$ ). Significant accumulation (up to +15 to $+20 \mathrm{~m}$ ) occurred in the lower part of the slope, at the border between transit zone and the left side of the ancient toe zone. Part of this earth flow, derived by the depletion of the transit zone, reached the riverbed, where it

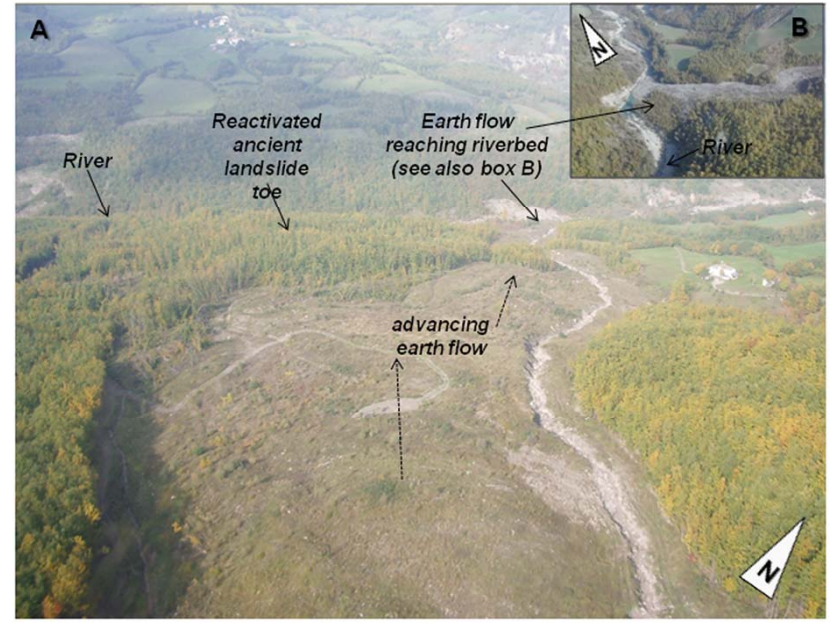

Fig. 4. Aerial views of the Valoria landslide toe. (A) view from top to down; (B) detail of the earth flow that reached the river bed in 2001 causing mass wasting.

was progressively eroded (Fig. 4). A depletion area was also evidenced in the ancient landslide toe (down to about -5 to $-8 \mathrm{~m}$ ). This is related to the formation of a pseudo-graben feature, consequence of river undercutting that started when the whole landslide toe underwent an "in-bulk" advancement into the riverbed. 


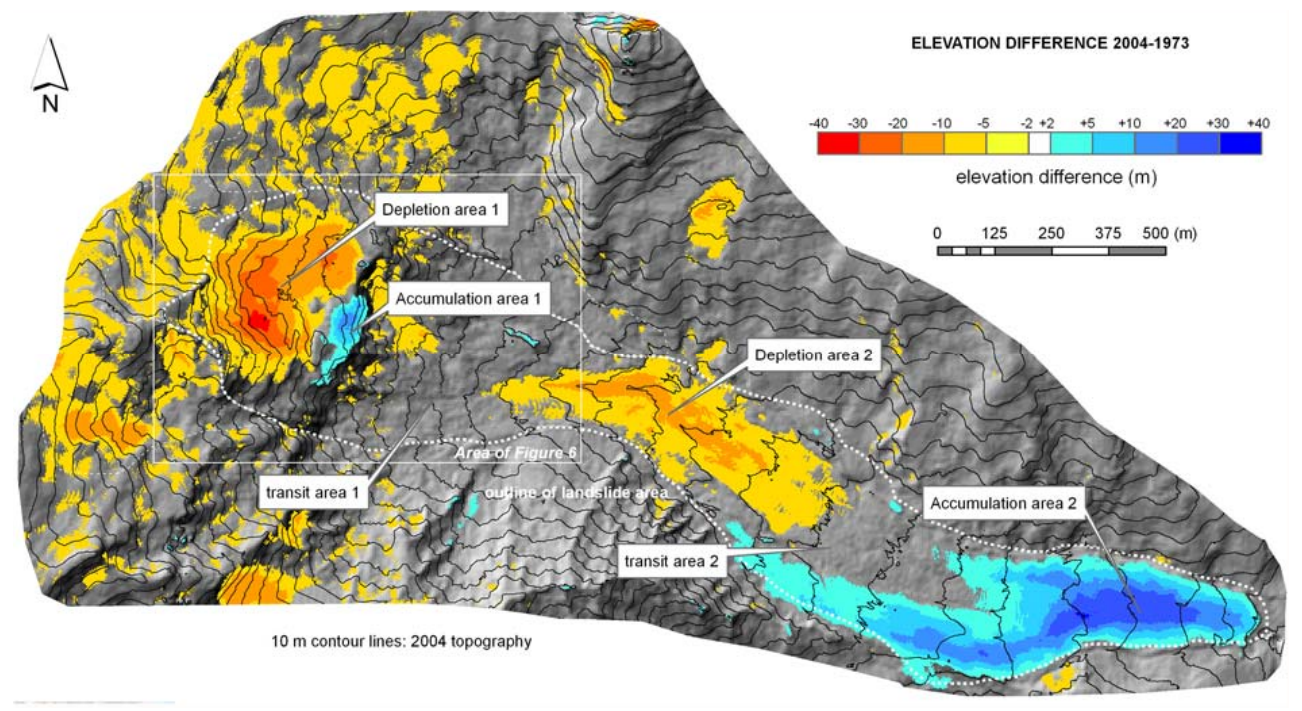

Fig. 5. Differential DEM 2004-1973 for Ca' Lita landslide (modified after Borgatti et al., 2006).

A second differential DEM product was created by subtraction of the 2003 and 2006 DEMs, so to bracket the 20052006 reactivation event (Fig. 3b). To do so, the $2006 \mathrm{Li}$ DAR DEM, originally at $0.5 \mathrm{~m}$ cell size, was resampled at $2 \mathrm{~m}$ cell size in order to average values in adjacent pixels, and to smooth the bias that could have eventually affected the differential DEMs using different cell size. Further depletion was evidenced in the upper portion of the source zone (down to $-10 \mathrm{~m}$ ), that was coupled with accumulation at some locations in the intermediate and lower part of the source zone itself (up to $+10 \mathrm{~m}$ ). Quite interesting is the significant accumulation in the transit zone (up to $+15 \mathrm{~m}$ ), that completely compensated the depletion created by the previous 2001 event. Some accumulation - or better uplift - in the order of $+3 \mathrm{~m}$ is visible in part of the toe zone. This is interpreted as a bulging of the toe caused by the compressive stress caused by the earth flow front filling the transit zone and loading the toe zone that, actually, was reactivated "in bulk". On the basis of GPS benchmarks measurements this process caused a displacement estimated in the order of $2 \mathrm{~m}$ (Ronchetti et al., 2007). During this event, limited erosion was operated by the river on the landslide toe, so sediment flux was basically null.

\subsection{Ca’ Lita landslide}

The Ca' Lita landslide can be more precisely classified as a rotational rock and earth slide - earth flow (Borgatti et al., 2006). This is due to the fact that, whereas down slope the landslide evolves as an earth slide - earth flow, in the upper slope the landslide evolves as a roto-traslational slide affecting weak rocks down to the depth of $-42 \mathrm{~m}$, as it was possible to determine by analysis of borehole cores and by inclinometer monitoring (Corsini et al., 2006).
A first differential DEM product was created by subtraction of the 1973 and 2004 DEMs so to bracket the 2002 and 2004 reactivation events (Fig. 5). It evidenced a significant depletion of about 15 to $20 \mathrm{~m}$ in the upper landslide part, that is interpreted as the result of deep-seated roto-traslational sliding (depletion area 1 in Fig. 5). This was partly compensated by an apparent accumulation to its front (accumulation area 1), that is actually the result of the local rotation and advancement of the front of the roto-traslational rock slide. This dynamic did also result in the displacement of loose clayey material toward the lower part of the slope (transit area 1), without significant elevation changes before and after. A second depletion area is clearly visible in the upper part of the earth flow lobe (depletion area 2). This is compensated by the huge accumulation area that formed at the landslide toe (accumulation area 2). Basically, during the 2004 event, the landslide advanced about $400 \mathrm{~m}$ into a previously unaffected valley, that was consequently filled by landslide deposits.

A second differential DEM product was created by subtraction of the LiDAR 2005 DEM to the 2004 photogrammetric DEM (Fig. 6a). To do so, the 2005 DEM, originally at $0.5 \mathrm{~m}$ cell size, was resampled at $2 \mathrm{~m}$ cell size. This product evidenced the continuation, during winter 2004-2005, of the deep-seated roto-traslational movements affecting the upper landslide (corresponding to depletion area 1 in Fig. 5). Actually, by visualizing the shaded reliefs of 2004 and 2005 (Fig. 6c and d), it is clear that this depletion is more specifically a sort of subsidence, resulting from the distension of the landslide mass during its pivoting around a stable rock ridge located to the south. Consequently, the accumulation in the front of this area is actually to be ascribed to the advancement of this front over a previous topographic "low". The 


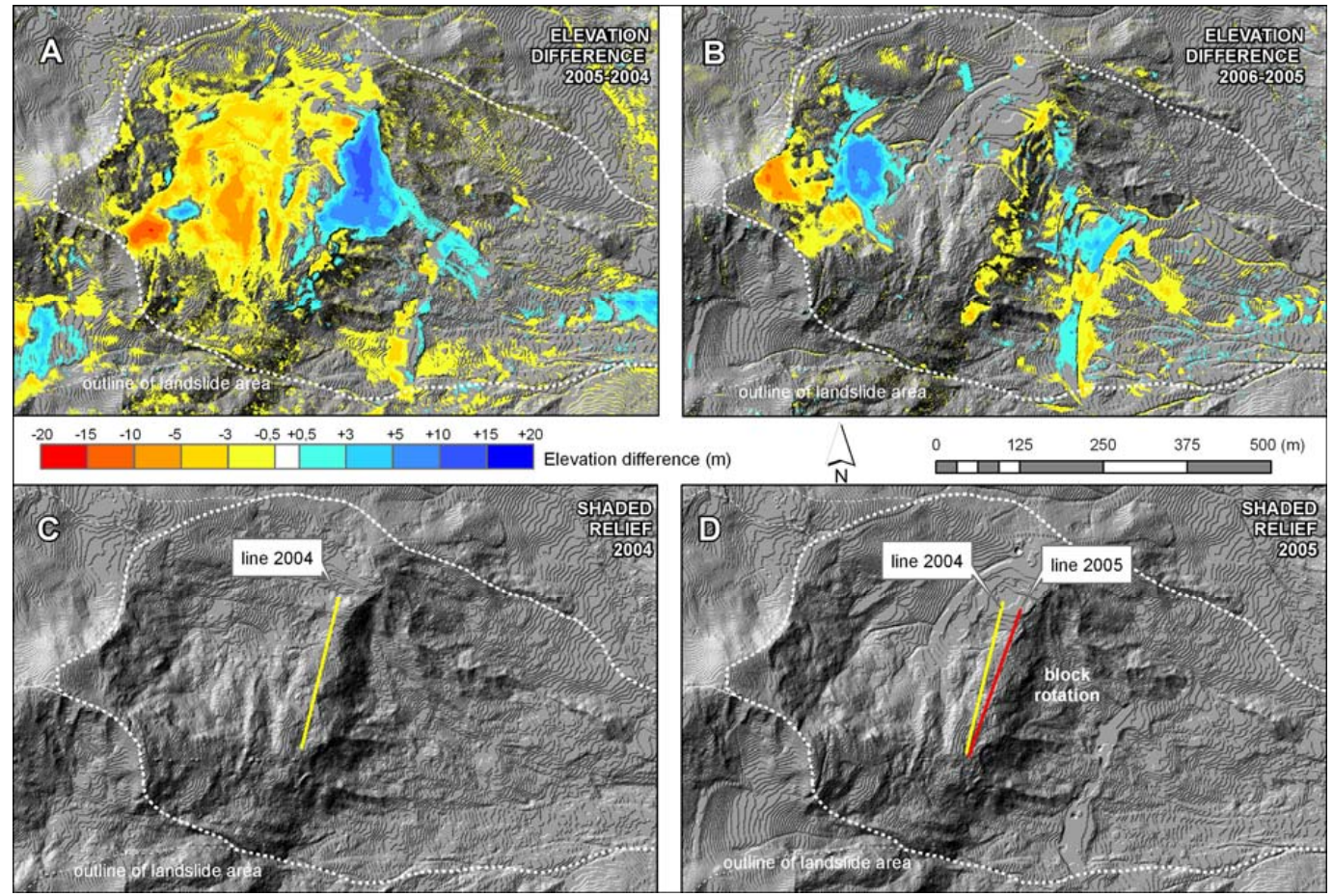

Fig. 6. Differential DEMs of the upper part of Ca' Lita landslide. (A) differential DEM 2005-2004; (B) differential DEM 2006-2005; (C) shaded relief of DEM 2004; (D) shaded relief of DEM 2005.

2004 and 2005 edge lines indicated in Fig. 6c and d were obtained by visual interpretation of the shaded reliefs and on the basis of field survey and mapping.

A third differential DEMs product was created by subtraction of the 2006 and 2005 LiDAR DEMs (Fig. 6b). This evidenced local collapses of the main scarp during winter 20052006. A depletion of more than $10 \mathrm{~m}$, and a deposition of material at the foot of the scarp is clearly visible. At the same time, this differential DEM product shows that deep-seated roto-traslational movements, active until summer 2005, were suspended during winter 2005-2006. This is to be ascribed to the positive effect of the deep drainage systems built in the slope during summer 2005.

\subsection{Analysis of mass wasting}

The differential DEMs of Figs. 3 and 5 are bracketing main reactivation events (i.e., Valoria 2001 and 2005-2006 and Ca' Lita 2002-2004). These products were further analysed in order to calculate cumulated depletion (D) and accumulation (A) and, ultimately, to assess mass wasting (defined as $\mathrm{X}=-\mathrm{D}+\mathrm{A})$.

Since the existing bias between DEMs could have affected the results derived from an automated sum of positive and negative elevation differences over the entire dataset, total accumulated and depleted volumes were computed only inside the landslide outline (defined on the basis geomorphic survey) and by considering only subareas in which the differential DEMs showed clearly that depletion or accumulation had occurred.

Furthermore, the total volume of material involved in each reactivation event was estimated by coupling the depletion, accumulation and mass waste data, with information about mass displacement, that is the part of the landslide that moves without causing evidence of elevation changes. This volume was assessed on the basis of underground exploration and monitoring data, and of field surveyed maps of the affected areas. The approach adopted is represented in Fig. 7.

The results of calculation are summarised in Table 1. In practice, only the Valoria 2001 reactivation event produced significant mass wasting (about 3 million $\mathrm{m}^{3}$ ). In all other cases, the mass balance between depletion and accumulation, i.e. mass wasting, is close to "zero". These figures, coupled with mass displacement information, allow assessing the total volumetric magnitude of the events. They were of about 15 million $\mathrm{m}^{3}$ and about 9 million $\mathrm{m}^{3}$ for the Valoria 2001 and 2006 events respectively, and of about 9 million $\mathrm{m}^{3}$ for the Ca' Lita events occurred between 2002 and 2004.

\section{Conclusions}

LiDAR has been successfully applied in different geomorphological settings and at different spatial scales on the one hand to improve landslide inventories (Van Den Eeckhaut et 
Table 1. Quantification of the different components of the volumetric magnitude of main reactivation events considered in Valoria and Ca' Lita.

\begin{tabular}{lllll}
\hline $\begin{array}{l}\text { Main Reactivation } \\
\text { Event }\end{array}$ & $\begin{array}{l}\text { Mass displacement } \\
\left(\mathrm{B}^{\prime}\right)\end{array}$ & $\begin{array}{l}\text { Mass Transfer } \\
(\mathrm{T})=\max \text { of }|-\mathrm{D}| \text { or } \\
|+\mathrm{A}|\end{array}$ & $\begin{array}{l}\text { Mass wasting } \\
(\mathrm{X})=(-\mathrm{D}+\mathrm{A})\end{array}$ & $\begin{array}{l}\text { Total volume } \\
(\mathrm{B})=\mathrm{B}^{\prime}+(|-\mathrm{D}|+|+\mathrm{A}|)-\mathrm{X}\end{array}$ \\
\hline Valoria 2001 & $\approx 9.0 \times 10^{6} \mathrm{~m}^{3}$ & $3.5 \times 10^{6} \mathrm{~m}^{3}$ & $-3.0 \times 10^{6} \mathrm{~m}^{3}$ & $\approx 15 \div 16 \times 10^{6} \mathrm{~m}^{3}$ \\
Valoria 2005-2006 & $\approx 7.0 \times 10^{6} \mathrm{~m}^{3}$ & $1.5 \times 10^{6} \mathrm{~m}^{3}$ & $+0.14 \times 10^{6} \mathrm{~m}^{3}$ & $\approx 8 \div 9 \times 10^{6} \mathrm{~m}^{3}$ \\
Calita 2002-2004 & $\approx 10 \times 10^{6} \mathrm{~m}^{3}$ & $2.0 \times 10^{6} \mathrm{~m}^{3}$ & $-0.2 \times 10^{6} \mathrm{~m}^{3}$ & $\approx 12 \div 13 \times 10^{6} \mathrm{~m}^{3}$ \\
\hline
\end{tabular}

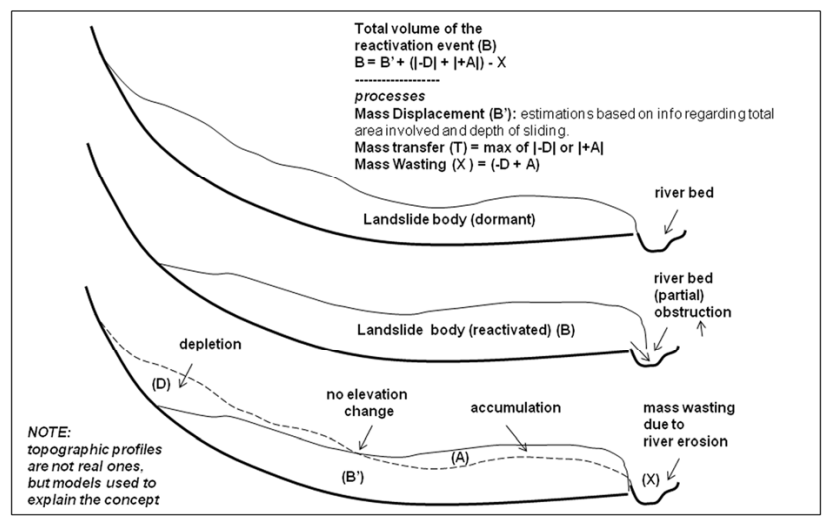

Fig. 7. Schematic drawing explaining the approach adopted for the quantification of the different components of the volumetric magnitude of reactivation events.

al., 2005) and on the other hand to perform geomorphometric studies on distinctive landslide features (McKean and Roering, 2004; Glenn et al., 2006; Wills, 2006).

The possibility of using time series of DEMs for evaluating volumetric magnitude of reactivation events has been exploited in this study. The usage of photogrammetric DEMs derived by existing topographic maps created some problems related to the elevation bias between the DEMs in stable areas (up to more than $1 \mathrm{~m}$ ). On the other hand, the bias between LiDAR DEMs was limited (maximum about $25 \mathrm{~cm}$ ), so that the quantification was more precise. Nevertheless, by using supervised procedures, it was still possible to evaluate, quantify and map depletion and accumulation zones at the landslide scale with DEMs of different source.

It must also be considered that the assessment of the total volume involved in a reactivation event was considered also mass displacement, that is not reflected in elevation changes (see Fig. 7). In landslides that are more than $3 \mathrm{~km}$ long and hundreds of metres wide, the assessment of mass displacement relies on data regarding the extent of the overall affected area (obtainable by field survey) and the extent and shape of the basal sliding surface (obtainable by interpolation of data from boreholes and geophysics). Therefore the assessment of the total volume of the event is only possible with an uncertainty of one or more million $\mathrm{m}^{3}$, that is much larger than that of the assessment of depletion and accumulation in the slope.

Nevertheless, the comparison of HR-DEMs provided an interesting insight on landslide mechanisms. Remarkable changes in topography caused by reactivation events were delimited and quantified in all the case study analysed. Disregard possible uncertainties, this piece of information is of great help in depicting possible future event scenarios. Moreover, considering that earth slides - earth flows moving at a rate up to $10 \mathrm{~m} /$ day are difficult to be monitored with field instrumentation, the results suggest that LiDAR systems could also be used, under certain organizational conditions (temporal resolution of the survey, cost, post-processing effort etc.), as a near-real time monitoring system during reactivation events as they provide a quick collection of topographical data and allow the representation of large surfaces with dense spatial sampling from which deformations of the ground surface of the landslide can be computed. In this way, the tensional state can be evaluated, together with a series of parameters useful for stability analyses.

Acknowledgements. The paper is part of project PRIN 2007 (Integrated Airborne and Wireless Sensor Network systems for landslide monitoring - WiseLand; local responsible: A. Corsini) and MarieCurie Project "Mountain Risks" (MRTN-CT-2006-035798).

The editor (Marc-Henri Derron) and the reviewers (Graziella Devoli and Anonymous) are acknowledged for the useful suggestions that allowed improving the manuscript.

Distinct collaboration: A. Corsini, L. Borgatti and F. Ronchetti prepared the paper and the figures. F. Cervi and A. Daehne contributed to the collection and elaboration of field data and DEMs. P. Sterzai was responsible of the acquisition and processing of LiDAR data.

Edited by: M.-H. Derron

Reviewed by: G. Devoli and another anonymous referee 


\section{References}

Bertolini, G.: Radiocarbon dating on landslides in the Northern Apennines (Italy), in: Landslide and Climate Changes: challenges and solutions, edited by: McInnes, R., Jakeways, J., Fairbank, H., and Mathie, E., Taylor \& Francis Group, London, 2007.

Borgatti, L., Corsini, A., Barbieri, M., Sartini, G., Truffelli, G., Caputo, G., and Puglisi, C.: Large reactivated landslides in weak rock masses: a case study from the Northern Apennines (Italy), Landslides, 3(2), 115-124, 2006.

Borgatti, L., Cervi, F., Corsini, A., Ronchetti, F., and Pellegrini, M.: Hydro-mechanical mechanisms of landslide reactivation in heterogeneous rock masses of the northern Apennines (Italy), AEG Special Publication, 23, 749-758, 2007.

Borgatti, L., Corsini, A., Marcato, G., Ronchetti, F., and Zabuski, L.: Appraise the structural mitigation of landslide risk via numerical modelling: a case study from the northern Apennines (Italy), Georisk: Assessment and Management of Risk for Engineered Systems and Geohazards, 2(3), 141-160, 2008.

Casson, B., Delacourt, C., and Allemand, P.: Contribution of multitemporal remote sensing images to characterize landslide slip surface? Application to the La Clapière landslide (France), Nat. Hazards Earth Syst. Sci., 5, 425-437, 2005,

http://www.nat-hazards-earth-syst-sci.net/5/425/2005/.

Corsini, A., Borgatti, L., Coren, F., and Vellico, M.: Use of multitemporal airborne LiDAR surveys to analyse post-failure behaviour of earthslides, Canadian J. Remote Sens., 33(2), 116120, 2007.

Corsini, A., Borgatti, L., Caputo, G., De Simone, N., Sartini, G., and Truffelli, G.: Investigation and monitoring in support of the structural mitigation of large slow moving landslides: an example from Ca' Lita (Northern Apennines, Reggio Emilia, Italy), Nat. Hazards Earth Syst. Sci., 6, 55-61, 2006,

http://www.nat-hazards-earth-syst-sci.net/6/55/2006/.

Gorte, B. G. H. and Koolhoven, W.: Interpolation between isolines based on the Borgefors distance transform, ITC Journal, Enschede, 3, 245-247, 1990.

Glenn, N. F., Streutker, D. R., Chadwick, D. J., Thackray, G. D., and Dorsch, S. J.: Analysis of LiDAR-derived topographic information for characterizing and differentiating landslide morphology and activity, Geomorphology, 73(1-2), 131-148, 2006.

Guibas, L. and Stolfi, J.: Primitives for the Manipulation of General Subdivisions and the Computation of Voronoi Diagrams, ACM Transactions on Graphics, 4(2), 74-123, 1985.
Jaboyedoff, M., Metzger, R., Oppikofer, T., Couture, R., Derron, M.-H., Locat, J., and Turmel, D.: New insight techniques to analyze rock-slope relief using DEM and 3-D-imaging cloud points: COLTOP-3-D software, in: Rock mechanics: Meeting Society's challenges and demands, edited by: Eberhardt, E., Stead, D., and Morrison, T., Proceedings of the 1st Canada - US Rock Mechanics Symposium, Vancouver, Canada, 27-31 May 2007, Taylor \& Francis, London, 61-68, 2007.

Manzi, V., Leuratti, E., Lucente, C. C., Medda, E., Guerra, M., and Corsini, A.: Hystorical and recent hydrogeological instability in the Monte Modino area: Valoria, Tolara and Lezza Nuova landslide reactivations (Dolo - Dragone valleys, Modena Apennines, Italy), GeoActa, 3, 1-13, 2004.

McKean, J. and Roering, J.: Objective landslide detection and surface morphology mapping using high-resolution airborne laser altimetry, Geomorphology, 57, 331-351, 2004.

Metternicht, G., Hurni, L., and Gogu, R: Remote sensing of landslides: An analysis of the potential contribution to geo-spatial systems for hazard assessment in mountainous environments, Remote Sens. Environ., 98, 284-303, 2005.

Regione Emilia-Romagna, Servizio Geologico Sismico e dei Suoli: Historical archive of landslide events, http://www.regione. emilia-romagna.it/wcm/geologia_en/Sections/Hydrogeological_ risk/Landslides_ER/10_historical_archive_landslide.htm, 2008.

Ronchetti, F., Borgatti, L., Cervi, F., Lucente, C. C., Veneziano, M., and Corsini, A.: The Valoria landslide reactivation in 2005-2006 (Northern Apennines, Italy), Landslides, 4(2), 189-195, 2007.

Terrasolid: TerraScan "software for processing airborne and mobile laser data and images", http://www.terrasolid.fi/en/products/4, 2005.

Van Den Eeckhaut, M., Poesen, J., Verstraeten, G., Vanacker, V., Moeyersons, J., Nyssen, J., and van Beek, L. P. H.: The effectiveness of hillshade maps and expert knowledge in mapping old deep-seated landslides, Geomorphology, 67(3-4), 351-363, 2005.

Van Westen, C. J. and Lulie Getahun, F.: Analyzing the evolution of the Tessina landslide using aerial photographs and digital elevation models, Geomorphology, 54, 77-89, 2003.

Wills, C. J.: Evaluation of LiDAR for Landslide Mapping, California Department of Transportation, http: //www.dot.ca.gov/newtech/researchreports/reports/2006/ LiDAR_final_report_6-30-06.pdf., 2006. 